\title{
BRYOPHYTE FLORA OF THE FORESTS OF VÉTYEM AND OLTÁRC PROTECTED AREAS (ZALA COUNTY, W HUNGARY)
}

\author{
Beáta PAPP* and Erzsébet SzURDOKI \\ Department of Botany, Hungarian Natural History Museum, \\ H-1431 Budapest,.Pf. 137, Hungary; *app.beata@nhmus.hu
}

Papp, B. \& Szurdoki, E. (2018): Bryophyte flora of the forests of Vétyem and Oltárc protected areas (Zala County, W Hungary). - Studia bot. hung. 49(1): 83-96.

\begin{abstract}
Altogether 102 bryophyte taxa (13 liverworts and 89 mosses) were collected. Two species are protected in Hungary and included in the Red data book of European bryophytes. Several other species are red-listed in Hungary; one is in the data deficient (DD) category (without any recent records for almost 50 years), two are vulnerable (VU). Further 14 species are near threatened (NT), 14 are in the least concern-need attention (LC-att) category, and 20 species are regarded as indicators, which by their mere presence represents a greater level of conservation value of the habitat. From nature conservation aspect the most important habitats are the humid valleys with temporary watercourses and the forests with rich epiphyte bryophyte flora.
\end{abstract}

Key words: European red-listed species, liverworts, mosses, nationally protected species

\section{INTRODUCTION}

Exploration of the bryophyte flora was carried out in 2017 in some previously bryologically less studied territory of the Balaton-felvidék National Park namely the forests of Vétyem and Oltárc Natura 2000 protected areas in Zala County. Mainly beech, oak and hornbeam forests are developed on clay and sandy soils in these protected sites. Climate is moderately cold and moderately humid with 700$750 \mathrm{~mm}$ annual precipitation. The average annual temperature is $9-10^{\circ} \mathrm{C}$.

Szurkosárok valley at Vétyem (Tormafölde) was known as the site of Dicranum viride, a protected species in Hungary, which is included in the Annex II of the EU Habitat Directive, as well. The valley was visited by Ádám Boros on 12.07.1955, when the above mentioned species and another nationally protected, European red-listed species Neckera pennata were collected (Boros 1955). He also visited next day some sites around Várfölde and Bázakerettye and he listed in his field diary altogether 24 species from this trip; 4 liverworts (Conocephalum conicum, Frullania dilatata, Lophocolea heterophylla, Nowellia curvifolia) and 20 mosses (Amblystegium serpens, Brachythecium rutabulum, Dicranella heteromalla, Dicranum flagellare, D. montanum, D. viride, Diphyscium foliosum, Herzogiella 
seligeri, Hypnum cupressiforme, Isothecium alopecuroides, Leucobryum glaucum, Neckera pennata, Plagiomnium undulatum, Platygyrium repens, Pleuridium subulatum, Pleurozium schreberi, Pohlia nutans, Pterigynandrum filiforme, Rhizomnium punctatum, Ulota crispa).

Besides that very few, sporadic bryophyte collections were carried out in the area. Árpád Károlyi collected a few species in 1948 in 'Budafa-erdö' forest at Lispe and in forests around Lenti, and in 1949 around Várfölde. His material was identified by Ádám Boros and László Vajda. Later on, Tamás Pócs and Ilona Gelencsér visited some forests between Kiscsehi and Tormafölde in 1954. Each bryologist mentioned above spent only one day in the area. As a continuation we also worked only one day in 2001 around Vétyem in the Beech Forest Reserve area in the frame of the Hungarian Biodiversity-monitoring System searching for Dicranum viride, which is a target taxon of species monitoring in Hungary. We confirmed the presence of a small population on a decaying log at the edge of the forest reserve (PAPP et al. 2003).

In the present paper we give an overview on the bryophyte flora of the forests of Vétyem and Oltárc Natura 2000 protected areas with a special attention to the species of conservation interest.

\section{METHODS}

Investigation of the bryophyte flora was carried out in July and August 2017. The studied sites can be seen in Figures 1-3. Bryophytes were collected from soil, bark of trees and decaying wood, occasionally from artificial rock wall or concrete elements. Specimens are deposited in the Bryophyte Collection of the Hungarian Natural History Museum (BP). Nomenclature of bryophytes follows PAPP et al. (2010) with two exceptions (Ulota crispula, U. intermedia), where the publication of CAPARRós et al. (2016) was used.

Collecting sites are the following:

1. Vétyem Protected Area, 'Bikacsa' forest, Kiscsehi, $46.50489^{\circ} \mathrm{N}, 16.66681^{\circ}$ E, $180 \mathrm{~m}$, 03.07.2017.

2. Vétyem Protected Area, 'Hosszú-hegyhát', Kiscsehi, $46.50778^{\circ} \mathrm{N}, 16.65131^{\circ}$ E, $250 \mathrm{~m}$, 04.07.2017.

3. Vétyem Protected Area, 'Hosszú-hegyhát', Kiscsehi, $46.50214^{\circ} \mathrm{N}, 16.64792^{\circ}$ E, $185 \mathrm{~m}, 04.07 .2017$.

4. Vétyem Protected Area, 'Hegy-erdő' forest, Maróc, $46.53331^{\circ} \mathrm{N}, 16.64453^{\circ}$ E, $300 \mathrm{~m}$, 04.07.2017.

5. Vétyem Protected Area, 'Nagy-völgy' valley, Vétyempuszta, at an artificial lake, $46.55408^{\circ} \mathrm{N}, 16.64781^{\circ} \mathrm{E}, 285 \mathrm{~m}, 23.08 .2017$. 
6. Vétyem Protected Area, 'Hottói-erdo"' forest, between Vétyempuszta and Maróc, $46.56206^{\circ} \mathrm{N}, 16.65194^{\circ} \mathrm{E}, 315 \mathrm{~m}, 23.08 .2017$.

7. Vétyem Protected Area, 'Pál-völgy' valley, 'Hottói-erdö' forest, Maróc, 46.56139 ${ }^{\circ} \mathrm{N}, 16.65650^{\circ} \mathrm{E}, 225 \mathrm{~m}, 23.08 .2017$.

8. Oltárc Protected Area, 'Haraszti-erdö' forest, Borsfa, $46.52608^{\circ} \mathrm{N}, 16.78381^{\circ}$ E, $185 \mathrm{~m}, 04.07 .2017$.

9. Oltárc Protected Area, 'Dalfi-erdő' forest, between Söjtör and Hahót, $46.64358^{\circ} \mathrm{N}, 16.87469^{\circ} \mathrm{E}, 300 \mathrm{~m}, 22.08 .2017$.

10. Oltárc Protected Area, 'Márton-erdő' forest, Söjtör and Hahót, at an artificial lake, $46.63908^{\circ} \mathrm{N}, 16.87975^{\circ} \mathrm{E}, 300 \mathrm{~m}, 22.08 .2017$.

11. Oltárc Protected Area, 'Mackó-forrás' source, Söjtör and Hahót, $46.64903^{\circ}$ $\mathrm{N}, 16.87864^{\circ} \mathrm{E}, 300 \mathrm{~m}, 22.08 .2017$.

12. Oltárc Protected Area, 'Szuloki-forrás' source, Valkonya, $46.49839^{\circ} \mathrm{N}$, 16.83042 ${ }^{\circ} \mathrm{E}, 250 \mathrm{~m}, 24.08 .2017$.

13. Oltárc Protected Area, artificial lake downstream of 'Szuloki-forrás', Valkonya, $46.49197^{\circ} \mathrm{N}, 16.83222^{\circ} \mathrm{E}, 230 \mathrm{~m}, 24.08 .2017$.

14. Oltárc Protected Area, 'Csuszigáló', between Valkonya and Rigyác, 46.49817 $\mathrm{N}, 16.84117^{\circ} \mathrm{E}, 200 \mathrm{~m}, 24.08 .2017$.

15. Oltárc Protected Area, east of 'Csuszigáló' at Rigyác, $46.50131^{\circ} \mathrm{N}$, 16.85092 ${ }^{\circ}$ E, $225 \mathrm{~m}, 24.08 .2017$.

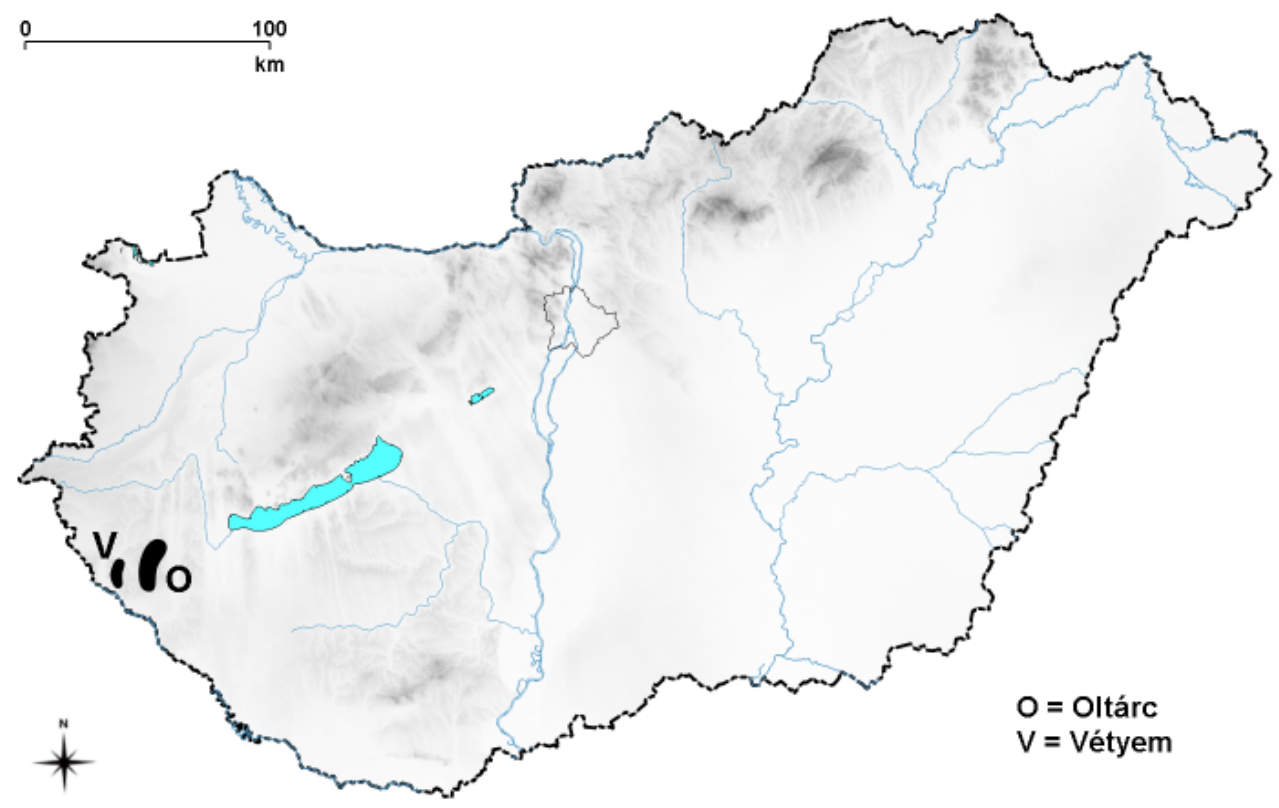

Fig. 1. Oltárc and Vétyem Natura2000 protected areas. 


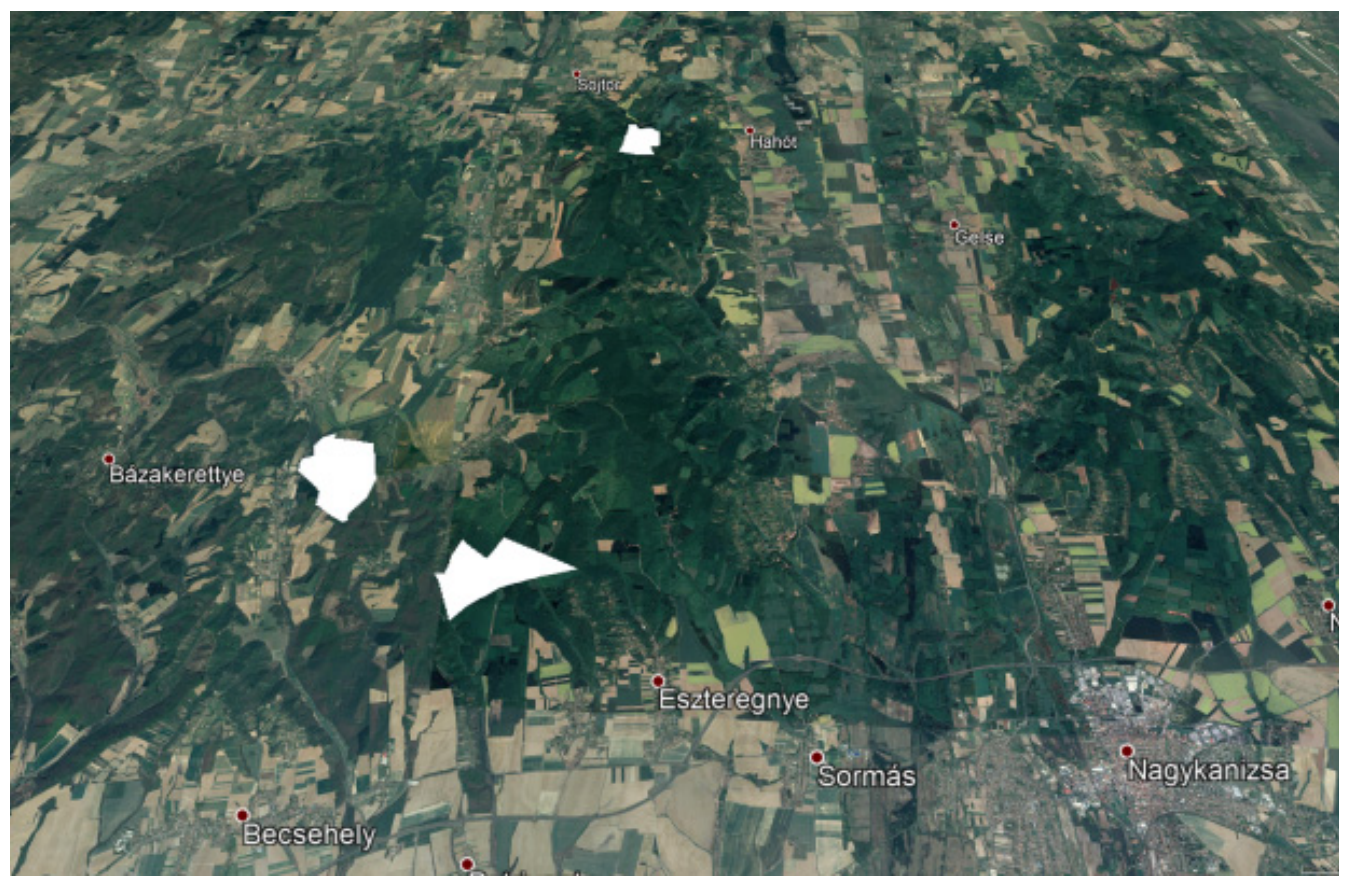

Fig. 2. Location of the studied forests in Oltárc Protected Area.

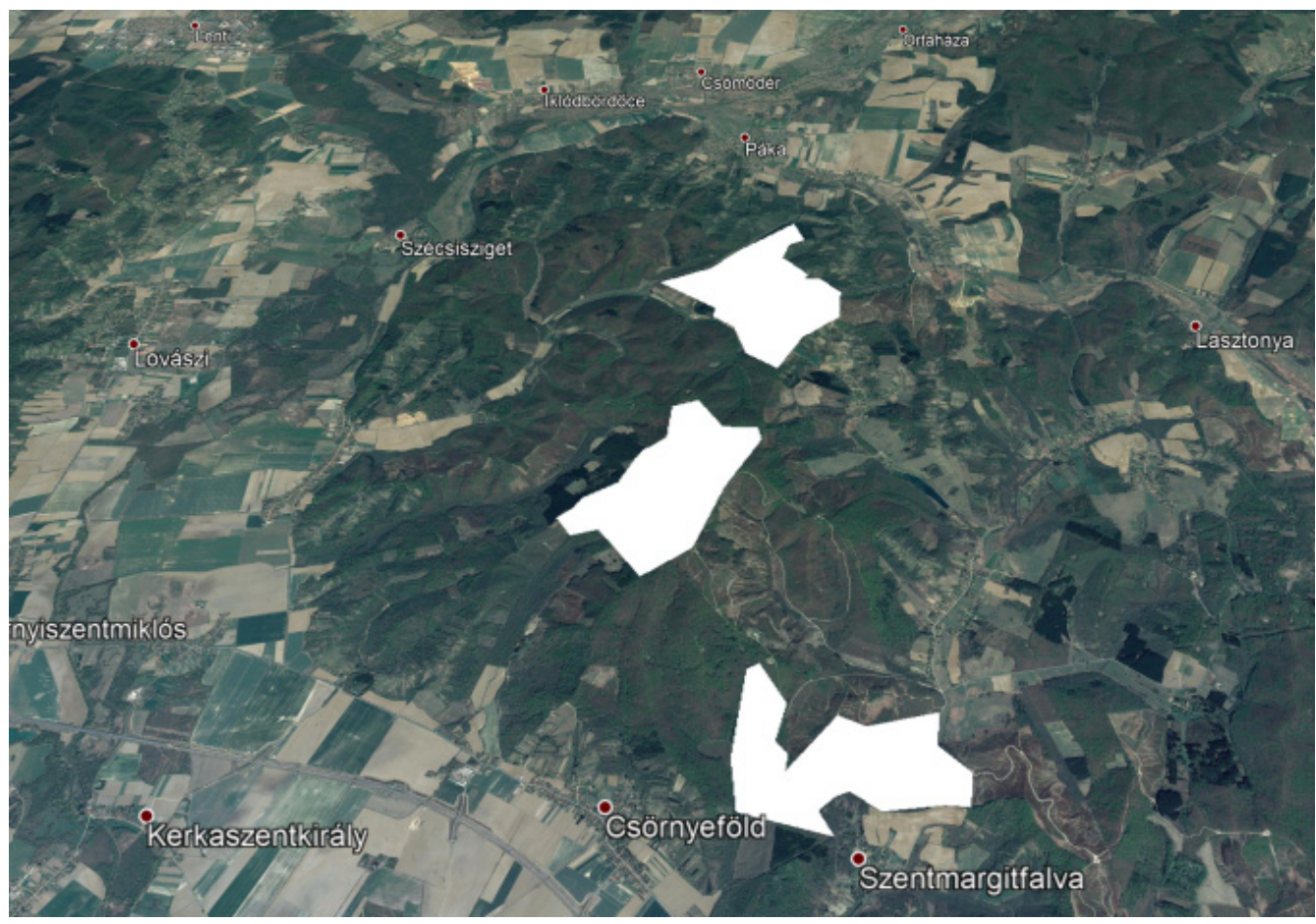

Fig. 3. Location of the studied forests in Vétyem Protected Area. 


\section{RESULTS AND DISCUSSION}

Altogether 102 bryophyte taxa (13 liverworts and 89 mosses) were collected. The list of the bryophyte taxa collected can be found in the Appendix.

\section{Bryophyte vegetation}

The epiphyte flora of the studied forests has high bryophyte diversity. In many places the bryophyte cover is very dense on the trees up to $1-1.5 \mathrm{~m}$ height. Hypnum cupressiforme and Platygyrium repens are the most frequent species, but on the lower part of the trees Anomodon attenuatus, Brachythecium rutabulum, B. salebrosum, Isothecium alopecuroides, and Homalia trichomanoides are also frequent and abundant, while Amblystegium subtile and Leucodon sciuroides are also characteristic species in some sites. The upper part of trees is covered by many liverworts like Frullania dilatata, Metzgeria furcata and Radula complanata, and species of Orthotrichaceae moss family (Orthotrichum affine, O. lyellii, O. patens, O. speciosum and Ulota crispula) are also abundant.

On decaying wood Herzogiella seligeri, Hypnum cupressiforme and Lophocolea heterophylla are the most important members of the bryophyte assemblage. In humid places and on the trunks of more advanced rotting stage Dicranum montanum is frequent.

The terricolous bryophyte flora appears mainly on the road sides, bank of ditches and steep slopes of 10-20 m deep mini-valleys, which are a characteristic feature of the relief. The most abundant species are as follows: Atrichum undulatum, Brachythecium rutabulum, B. velutinum, Dicranella heteromalla, Eurhynchium hians, Fissidens taxifolius, Plagiomnium cuspidatum, Plagiothecium cavifolium and Polytrichum formosum. In some sites Eurbynchium angustirete, E. schleicheri, Fissidens bryoides and Plagiomnium rostratum are also frequent. On the wet muddy walls of car wheel traces Poblia melanodon is the most characteristic species. On the bank of ditches with watercourses and along streams Conocephalum conicum, a thalloid liverwort, appears and the occurrence of Mniaceae species (Mnium marginatum, M. stellare, Plagiomnium undulatum, Rhizomnium punctatum) are characteristic.

\section{Species of conservation interest}

Two species found are protected in Hungary and included in the Red data book of European bryophytes (ECCB 1995). Several other species are red-listed in Hungary (PAPP et al. 2010); one is in the data deficient (DD) category (without any recent records for almost 50 years), two are vulnerable (VU). Further 14 species are near threatened (NT), 14 are in the least concern-need attention (LC-att) 
category, and 20 species are regarded as indicators, which by their mere presence represents a greater level of conservation value of the habitat.

\section{Dicranum viride}

Dicranum viride is a species of the temperate zone of Europe (DüLL 1984). It occurs on the bark of trees in humid forests and occasionally on decaying wood. It is included in the Annex II of EU Habitat Directive, and in the Bern Convention; it is vulnerable (VU) according to the Red data book of European bryophytes (ECCB 1995). It is protected in Hungary and also included in the Hungarian Red List of Bryophytes as vulnerable (VU) (PAPP et al. 2010).

The field identification of the species is very difficult and doubtful due to the resemblance to another relative in the genus, $D$. tauricum, which lives in the same habitat and sometimes even on the same tree (PAPP et al. 2002).

In Hungary 14 extant populations are known mainly in the Northern Hungarian Mountain Range, e.g. Bükk Mts (5 populations), Zemplén Mts (3), Börzsöny Mts (1), Pilis Mts (1); a few in Eastern Hungary as Bátorliget (1) and Bereg region (1); two in Western Hungary in Örség region and Vétyem (Tormafölde) (PAPP et al. 2003, P. Erzberger, B. Papp unpublished). The population size is usually small; mostly it occurs with 1-2 patches on 1 tree. Larger populations can be found in the Bükk Mts (Hór-völgy, Öserdő) and in the swamp forest at Bátorliget, but the population size is less than 50 everywhere, maximum 50 trees are inhabited.

Earlier data from Zala were collected from decaying wood in 1955 by Ádám Boros in Szurkosárok valley at Vétyem (Tormafölde). This population is probably existing as in 2001 the authors found the species in a stream valley at the edge of the Vétyem Forest Reserve area. Only one large decaying beech trunk was covered by a $57 \mathrm{~cm}^{2}$ patch of the species (PAPP et al. 2003).

During the recent investigation it was found in Hosszú-hegyhát forest at Kiscsehi. The area belongs to the Vétyem Protected Area. A small patch $\left(1 \mathrm{~cm}^{2}\right)$ occurred accompanied by Dicranum montanum on a decaying log in a humid, shady valley bottom in a beech forest, where temporary rivulet flows. The species is very threatened and hardly survives in the site, as the supply of large decaying logs is uninsured. Forest cutting and thinning in the surroundings cause drier microclimate which cannot be compensated by the temporary watercourses having unpredictable and small water yield.

\section{Neckera pennata}

Neckera pennata is a subboreal species (DüLL 1985) being vulnerable (VU) according to the Red data book of European bryophytes (ECCB 1995). It is pro- 
tected in Hungary and included in the Hungarian red list of bryophytes as endangered (EN) species (PAPP et al. 2010).

In Hungary 4 extant populations are known; 2 in Bereg region (PAPP 2008, P. Szücs unpubl.), 1 from the Örség region (Szücs 2009) and 1 from Zala County (Z. Purger unpubl.). The populations are very small occurring only on 1-2 trees each.

In Zala County in the vicinity of our investigated areas Zoltán Purger collected two specimens in 2008 in Kozári forest at Bázakerettye.

During the recent survey the species was found in 'Pál-völgy' valley in 'Hottói-erdo’' forest at Maróc. The site belongs to the Vétyem Protected Area. Two palm-size patches were discovered on one Fraxinus excelsior tree at 0.5 and $1 \mathrm{~m}$ height. The tree stands in a valley bottom. The survival of the species here is very doubtful as there are only few large Fraxinus trees which seem to be the target of forest activity. Forest cutting and thinning are very intense in the surroundings, which affect the microclimate as well causing drier conditions.

\section{Plagiothecium platyphyllum}

Plagiothecium platyphyllum is a subatlantic species with montane character (DÜLL 1985). It occurs on acidic soil in forests, on roadsides, at the bottom of trees (ORBÁN and VAJDA 1983), in rock crevices at waterfalls, and streams in mountain habitats (SMITH 2004). It is in the data deficient (DD) category in the Hungarian Red List of Bryophytes (PAPP et al. 2010), which means that it has not been collected in the last 50 years. After the publication of the red list some data arose; at Szőce wetland in Örség, in the Jeli Arboretum at Kám and in the Mecsek Mts at Cserkút (B. Papp unpublished). In the Hungarian localities it was found at the base of trees and on wet soil at streams or ponds. During our recent investigation it was collected in the Vétyem protected area near Vétyempuszta at an artificial lake at the base of an Alnus tree.

\section{Nowellia curvifolia}

Nowellia curvifolia is a subatlantic tiny leafy liverwort with montane character (DÜLL 1983), living on decaying wood. It is vulnerable (VU) according to the Hungarian red list of bryophytes (PAPP et al. 2010). It has several data from the western part of Hungary mainly from Vas County, but rare and sporadic elsewhere; some small extant populations in Bükk Mts, Börzsöny Mts, Mátra Mts and Pilis Mts. On the base of our recent knowledge it seems that its Hungarian threat status was overestimated in 2010. In Zala County Árpád Károlyi collected it in 1949 and Ádám Boros in 1955 at Várfölde. During the recent study it was collected in Oltárc Protected Area, in 'Haraszti-erdő' forest at Borsfa. A palm-size patch was found on a large decaying trunk in a ditch with temporary watercourse. 


\section{Orthotrichum patens}

Orthotrichum patens is an Atlantic, Mediterranean epiphyte moss (DüLL 1985). It is vulnerable (VU) according to the Hungarian red list of bryophytes (PAPP et al. 2010). Last years several data of this species have arisen, hence its Hungarian threat status is overestimated and should be updated. In the subsequent national red list it can be placed in the least concern-need attention (LCatt) category. In the studied forests it was very frequent and abundant, occurring on various tree species.

\section{Near threatened species}

Several species of near threatened (NT) category in Hungary (PAPP et al. 2010) were found during our survey. Most of these species have been collected in many Hungarian localities in the last years due to the intensive and thorough bryological investigations, therefore they are much more frequent than we have thought before. In the next national red list they will be placed in the least concernneed attention (LC-att) category. These are Cirriphyllum piliferum, Eurhynchium pulchellum, E. schleicheri and E. striatum, all occur on bare soil in forests or roadsides. They are very similar to other frequent Eurbynchium or Brachythecium species; hence they are under-collected. Diphyscium foliosum and Pseudotaxiphyllum elegans are characteristic species of acidic soil in forests. Aneura pinguis, a thalloid liverwort is not rare on wet places. Mnium lycopodioides also lives on moist soil on the bank of ditches or streams. Anomodon longifolius grows on shaded rocks and on bark of the lower parts of trees. It is rarer than its relatives $(A$. attenuatus and $A$. viticulosus) living in similar habitats, but it is widespread throughout the country. The same can be stated about the small epiphyte Orthotrichum species, like Orthotrichum obtusifolium and O. pumilum.

There are some really rare, near threatened species in the study area. Tortula latifolia is an epihyte moss of the temperate zone of Europe (DüLL 1985). Its recent records have been found mainly along the riparian forests of the Danube River and its tributaries. Apart from these, it has few data e.g. from the Cserhát Mts, the Bakony Mts and from a Populus tree at Mikládi wetland at the foothill of the Bakony Mts (P. Erzberger, B. Papp unpublished). Hence its occurrence on a Fagus tree in the forest between Söjtör and Hahót is an interesting data.

Calypogeia fissa, a subatlantic, Mediterranean small leafy liverwort (DüLL 1983) has only a few records. In the western part of Hungary, in Örség region it is not rare, but elsewhere it has only sporadic occurrences; some populations in the Bakony, the Vértes Mts and the Mecsek Mts (Cs. Németh, B. Papp, P. Erzberger unpublished). During the recent survey it was found on steep roadsides in 'Haraszti-erdo’' forest at Borsfa and in the forest between Söjtör and Hahót. 
Another species or species complex has to be mentioned. Ulota crispa (Hedw.) Brid. is near threatened (NT) in Hungary (PAPP et al. 2010). During our recent study, for the identification of Ulota specimens the paper of CAPARRós et al. (2016) was used, which divides the Ulota crispa complex into three species; $U$. crispa s.s., $U$. crispula Bruch, $U$. intermedia Schimp. On the basis of this most of our specimens were Ulota crispula. U. crispa s.s. was not rare either but $U$. intermedia was collected only in one locality. Usually many Ulota were found in the studied forests in all tree species, but the three Ulota species co-occurred only in 'Bikacsa' forest at Kiscsehi.

Acknowledgements - The study was financially supported by the Balaton-felvidék National Park. We are grateful to László Lőkös for his help in the fieldwork and to Peter Erzberger and Csaba Németh for providing some of their unpublished data of rare species in Hungary.

Összefoglaló: A Balaton-felvidéki Nemzeti Parkhoz tartozó olyan területeken végeztünk mohaflóra-feltárást 2017-ben, ahonnan korábbról csak kevés adat volt. Ilyenek a Natura 2000-es Vétyem és Oltárc területek Zala megyében, ahol többnyire bükkösök és gyertyános-tölgyesek fordulnak elő agyagos, homokos talajon. Jelen cikkben a vizsgált erdők mohavegetációjára vonatkozó ismereteinket és a mohaflórájuk természetvédelmi értékelését foglaltuk össze. Összesen 102 mohafajt (13 májmohát és 89 lombosmohát) mutattunk ki a vizsgált területről. Két, hazánkban védett Európai Vörös Könyves (Dicranum viride, Neckera pennata); egy Magyarországon adathiányos (DD), azaz az utóbbi 50 évben nem gyüjtött (Plagiothecium platyphyllum); két Magyarországon sérülékeny (VU) (Nowellia curvifolia, Orthotrichum patens); 14 veszélyeztetettséghez közeli (NT), 14 nem veszélyeztetett, de figyelmet érdemlő (LC-att) és 20 élőhelyének jó természetvédelmi állapotára utaló, ún. indikátor mohafaj került elő a vizsgálataink során. Az erdők többségének az epifiton mohaflórája igen fajgazdag, helyenként a fák törzsét akár 1-1,5 m-ig is sűrű mohaborítás fedi. A fák felsőbb részén pedig nagy mennyiségben fordulnak elö májmohák, mint pl. Frullania dilatata, Metzgeria furcata, Radula complanata és az Orthotrichaceae lombosmohacsalád tagjai (Orthotrichum és Ulota fajok). Természetvédelmi szempontból a legértékesebb élőhelyek azok a nedves, hűvös völgyaljak, amelyeket érintetlenebb erdő vesz körül.

\section{REFERENCES}

Boros, Á. (1955): Florisztikai jegyzetek, 41. [Field diaries, 41.] - Manuscript, Hungarian Natural History Museum, Budapest.

Caparrós, R., Lara, F., Draper, I., Mazimpaka, V. and Garilleti, R. (2016): Integrative taxonomy sheds light on an old problem: the Ulota crispa complex (Orthotrichaceae, Musci) - Bot. J. Linn. Soc. 180: 427-451.

DüLL, R. (1983): Distribution of the European and Macaronesian liverworts (Hepaticophytina). - Bryol. Beitr. 2: 1-115.

DüLL, R. (1984): Distribution of the European and Macaronesian mosses (Bryophytina) I. - Bryol. Beitr. 4: 1-109.

DüLL, R. (1985): Distribution of the European and Macaronesian mosses (Bryophytina) II. Bryol. Beitr. 5: 110-232. 
ECCB (1995): Red data book of European bryophytes. - European Committee for Conservation of Bryophytes, Trondheim, $291 \mathrm{pp}$.

OrbÁN, S. and VAJDA, L. (1983): Magyarország mohaflórájának kézikönyve. (Handbook of the Hungarian bryoflora). - Akadémiai Kiadó, Budapest, 518 pp.

PAPP, B. (2008): Selection of Important Bryophyte Areas in Hungary. - Folia Cryptog. Estonica 44: 101-111.

PAPP, B., ÓDOR, P. and SZURDOKI, E. (2002): An overview of options and limitations in the monitoring of endangered bryophytes in Hungary. - Novit. Bot. Univ. Carol., Praha, 15: 45-58. (2001).

PAPP, B., ÓdoR, P. and SzURDoki, E. (2003): Threat status of some protected bryophytes in Hungary. - Acta Acad. Paed. Agriensis, Sect. Biol. 24: 189-200.

PAPP, B., Erzberger, P., Ódor, P., Hock, Zs., SzÖvéNYi, P., SZURdoki, E. and Tóth, Z. (2010): Updated checklist and red list of Hungarian bryophytes. - Studia bot. hung. 41: 31-59.

SMith, A. J. E. (2004): The moss flora of Britain and Ireland. - Cambridge University Press, Cambridge, $739 \mathrm{pp}$.

SzűCs, P. (2009): Mohaflorisztikai vizsgálatok az Örség területén. [Bryofloristic investigation in the territory of Örség, Hungary]. - Praenorica Folia Hist.-Nat. 11: 13-48.

(submitted: 31.05 .2018 , accepted: 20.06.2018)

\section{Appendix}

Enumeration of the bryophyte taxa found in Vétyem and Oltárc protected areas. After the name the Hungarian red list status and indicator character of the species (PAPP et al. 2010) are given in brackets, which are followed by the number of collecting sites and substrates.

\section{Liverworts}

Aneura pinguis (L.) Dumort., (NT, indicator) - 8: soil

Calypogeia fissa (L.) Raddi, (NT, indicator) - 8, 10: soil

Cephalozia bicuspidata (L.) Dumort., (LC-att, indicator) - 10: soil

Conocephalum conicum (L.) Dumort. - 3: soil on the bank of a ditch; 8: soil; 11: soil on the bank of a stream; 12: artificial rock wall; 13: soil on the bank of a lake

Frullania dilatata (L.) Dumort. - 1, 3, 6, 12: Fagus bark; 2, 14: Quercus bark; 4, 8: bark of Fagus and Quercus; 5: bark of Carpinus and Fagus; 9: bark of Carpinus, Quercus and Fagus; 10: Salix bark

Lophocolea heterophylla (Schrad.) Dumort. - 1, 3, 5, 11: decaying wood; 8: soil and decaying wood; 10: soil; 12: soil, artificial rock wall and decaying wood; 14: decaying wood in a ditch

Marchantia polymorpha L. subsp. polymorpha - 8: soil

Metzgeria furcata (L.) Dumort. - 1, 3, 4, 12: Fagus bark; 2, 9, 14: Quercus bark; 5: bark of Quercus, Carpinus and Fraxinus; 7: Fraxinus bark; 8: bark of Tilia and Quercus 
Nowellia curvifolia (Dicks.) Mitt., (VU, indicator) - 8: decaying wood

Plagiochila porelloides (Nees) Lindenb. - 1: Quercus bark; 3: soil on the bank of a ditch; 10: soil; 12: artificial rock wall

Porella platyphylla (L.) Pfeiff. - 1, 4: Quercus bark; 3, 12: Fagus bark; 7: Fraxinus bark; 9: bark of Fagus and Quercus

Radula complanata (L.) Dumort. - 1: bark of Fagus and Quercus; 2, 9, 14: Quercus bark; 3, 6, 12: Fagus bark; 5: bark of Quercus, Carpinus and Fraxinus; 7: Fraxinus bark; 8: bark of Tilia, Fagus and Quercus

Riccia fluitans L., emend. Lorb., (LC-att, indicator) - 10: in the lake

\section{Mosses}

Amblystegium serpens (Hedw.) Schimp. - 2, 12: Fagus bark; 5: decaying wood; 8: bark of Tilia and Quercus; 10: soil on the bank of a lake; 13: rock on the bank of a lake; 14: Quercus bark

Amblystegium subtile (Hedw.) Schimp. - 1, 2, 4, 8: Quercus bark; 5: bark of Fraxinus and Acer pseudo-platanus; 7: Fraxinus bark; 14: bark of Fagus and Quercus

Amblystegium varium (Hedw.) Lindb., (LC-att, indicator) - 5: bottom of Alnus

Anomodon attenuatus (Hedw.) Huebener - 1: bark of Fagus and Quercus; 2, 8, 9: Quercus bark; 3: bark of Acer campestre; 5: bark of Fraxinus and Acer pseudoplatanus; 12: artificial rock wall; 14: Carpinus bark

Anomodon longifolius (Brid.) Hartm., (NT, indicator) - 1: Quercus bark

Anomodon viticulosus (Hedw.) Hook. et Taylor - 1, 8: Quercus bark; 3: bark of Acer campestre

Atrichum undulatum (Hedw.) P. Beauv. - 1, 2, 4, 5, 7, 8, 9, 10, 12: soil; 11 : soil on the bank of a stream

Barbula convoluta Hedw. - 8: soil

Barbula unguiculata Hedw. - 4, 8: soil

Brachythecium populeum (Hedw.) Schimp. - 1, 2, 8: Quercus bark; 12: Fagus bark; 14: decaying wood in a ditch

Brachythecium rutabulum (Hedw.) Schimp. - 1, 4: soil, bark of Fagus and Quercus; 2: soil and Quercus bark; 5: soil and bark of Acer pseudo-platanus; 7: soil and Fraxinus bark; 8: Quercus bark; 9: soil and Carpinus bark; 10: soil and Salix bark; 12: soil and artificial rock wall, Fagus bark and decaying wood

Brachythecium salebrosum (F. Weber et D. Mohr) Schimp. - 2: Quercus bark; 4: soil and Quercus bark; 5: soil, decaying wood and bark of Acer pseudoplatanus; 8: bark of Tilia and Quercus; 9: soil

Brachythecium velutinum (Hedw.) Schimp. - 1: bottom of Quercus; 2, 4, 7, 9: soil; 5: bark of Fraxinus and Fagus; 8, 14: Quercus bark; 12: soil and decaying wood 
Bryum capillare Hedw. - 2, 3: soil

Bryum rubens Mitt. - 2, 4: soil

Campylium calcareum Crundw. et Nyholm - 3: soil on the bank of a ditch

Ceratodon purpureus (Hedw.) Brid. - 4, 8: soil

Cirriphyllum piliferum (Hedw.) Grout, (NT, indicator) - 2: soil

Ctenidium molluscum (Hedw.) Mitt. - 4: soil; 12: artificial rock wall

Ctenidium molluscum (Hedw.) Mitt. var. condensatum (Schimp.) Britt. - 1, 15: bottom of Quercus; 7: Fraxinus bark

Dicranella beteromalla (Hedw.) Schimp. - 2, 4, 7, 8, 9: soil

Dicranella schreberiana (Hedw.) Hilf. ex H. A. Crum et L. E. Anderson 4: soil

Dicranella varia (Hedw.) Schimp. - 1, 5: soil

Dicranum montanum Hedw. - 1, 3, 4, 7, 8: decaying wood

Dicranum scoparium Hedw. - 4: soil and decaying wood

Dicranum tauricum Sapjegin - 4: decaying wood

Dicranum viride (Sull. et Lesq.) Lindb., (VU) - 3: decaying wood

Didymodon fallax (Hedw.) R. H. Zander - 8, 10: soil

Didymodon luridus Hornsch. ex Spreng. - 13: rock on the bank of a lake

Diphyscium foliosum (Hedw.) D. Mohr, (NT, indicator) - 4: soil

Encalypta streptocarpa Hedw. - 3: soil on the bank of a ditch

Eurhynchium angustirete (Broth.) T. J. Kop. - 1: bottom of Quercus; 7, 8: soil; 11: soil in Pinetum

Eurhynchium hians (Hedw.) Sande Lac. - 1, 2, 8, 9: soil; 5: decaying wood; 11: soil on the bank of a stream; 12: artificial rock wall

Eurbynchium pulchellum (Hedw.) Jenn., (NT, indicator) - 2: soil

Eurhynchium schleicheri (R. Hedw.) Jur., (NT) - 4, 5, 9, 12: soil

Eurhynchium striatum (Hedw.) Schimp., (NT) - 10: soil

Fissidens bryoides Hedw. - 2, 4, 8: soil

Fissidens taxifolius Hedw. - 1, 2, 3, 4, 5, 7, 8: soil; 11: soil on the bank of a stream

Funaria hygrometrica Hedw. - 8: soil

Herzogiella seligeri (Brid.) Z. Iwats. - 1, 3, 7, 8, 12: decaying wood

Homalia trichomanoides (Hedw.) Schimp., (LC-att, indicator) - 1: bark of Fagus and Quercus; 2, 4, 8: Quercus bark; 3: bark of Fagus and Acer campestre; 5: bark Fraxinus and Acer pseudo-platanus; 7: Fraxinus bark; 10: bark of Robinia pseudo-acacia; 14: roots of trees in a ditch, bark of Quercus and Fagus

Homalothecium sericeum (Hedw.) Schimp. - 2, 9: Quercus bark

Hypnum cupressiforme Hedw. - 1: bark of Fagus and Quercus; 2, 4, 12: Quercus bark; 3, 6: Fagus bark; 5: bottom of Alnus and Acer pseudo-platanus; 8: Fagus bark and decaying wood; 9: soil, bark of Carpinus, Quercus cerris and $Q$. petraea; 10: soil; 14: Carpinus bark 
Hypnum pallescens (Hedw.) P. Beauv. - 1: Fagus bark; 7: decaying wood

Isothecium alopecuroides (Dubois) Isov. - 1: bottom of Quercus; 2, 4, 8, 9 , 14: Quercus bark; 5: bottom of Alnus; 7, 10: soil; 12: Fagus bark

Leptodictyum riparium (Hedw.) Warnst. - 3: decaying wood in a ditch; 5: decaying wood; 8: decaying wood in small pond in the forest; 10: soil on the bank of a lake; 13: rock on the bank of a lake, Salix bark and decaying wood

Leskea polycarpa Ehrh. ex Hedw. - 5: decaying wood; 9, 12: Fagus bark; 10, 13: Salix bark

Leucodon sciuroides (Hedw.) Schwägr. - 1, 2, 4, 9, 15: Quercus bark; 5: bark of Fraxinus and Acer pseudo-platanus

Mnium lycopodioides Schwägr., (NT) - 3: soil on the bank of a ditch; 11: soil on the bank of a stream

Mnium marginatum (Dicks.) P. Beauv., (LC-att, indicator) - 8: soil; 11: soil on the bank of a stream; 14: decaying wood in a ditch

Mnium stellare Hedw., (LC-att, indicator) - 3: soil on the bank of a ditch; 7, 8: soil; 14: tree roots in a ditch

Neckera complanata (Hedw.) Huebener - 1: Quercus bark

Neckera pennata Hedw., (EN) - 7: Fraxinus bark

Orthotrichum affine Schrad. ex Brid. - 1, 3, 4, 6: Fagus bark; 2: Quercus bark; 7: Fraxinus bark; 8: Carpinus bark; 9: bark of Quercus cerris and Fagus; 10: Salix bark

Orthotrichum lyellii Hook. et Taylor - 1, 2: Quercus bark; 4: bark of Fagus and Quercus; 9: bark of Quercus cerris and Q. petraea

Orthotrichum obtusifolium Brid., (NT, indicator) - 10: Salix bark; 12: Fagus bark

Orthotrichum pallens Bruch ex Brid. - 4, 6: Fagus bark; 7: Fraxinus bark; 10: Salix bark

Orthotrichum patens Bruch ex Brid., (VU) - 1, 3, 6: Fagus bark, 12; 2: Quercus bark; 4: bark of Fagus and Quercus; 8: Carpinus bark; 9: bark of Fagus, Quercus cerris and Q. petraea; 10: Salix bark; 14: bark of Carpinus and Quercus

Orthotrichum pumilum Sw., (NT, indicator) - 4: Fagus bark; 10: Salix bark

Orthotrichum speciosum Nees, (LC-att, indicator) - 1: Fagus bark; 2: Quercus bark; 4: bark of Fagus and Quercus; 7: Fraxinus bark; 8: Carpinus bark; 9: bark of Fagus, Quercus cerris and Q. petraea; 10: Salix bark

Orthotrichum stramineum Hornsch. ex Brid. - 12: Fagus bark

Orthotrichum striatum Hedw., (LC-att, indicator) - 2: Quercus bark; 8: Carpinus bark; 9: bark of Quercus cerris and Q. petraea

Physcomitrium pyriforme (Hedw.) Brid. - 5: soil

Plagiomnium affine (Blandow) T. J. Kop. - 8: soil 
Plagiomnium cuspidatum (Hedw.) T. J. Kop. - 1, 2, 4: soil and Quercus bark; 5: decaying wood; 7: soil; 8: soil, bark of Fagus and Quercus; 10: soil and bark of Robinia pseudo-acacia; 12: soil and decaying wood; 13: rock on the bank of a lake; 14: tree roots in a ditch

Plagiomnium rostratum (anon.) T. J. Kop. - 2: soil; 11: soil on the bank of a stream; 12: artificial rock wall; 13: soil on the bank of a lake

Plagiomnium undulatum (Hedw.) T. J. Kop. - 2, 4, 8: soil; 5: bottom of Alnus; 11: soil in Pinetum and on the bank of a stream; 13: soil on the bank of a lake

Plagiothecium cavifolium (Brid.) Z. Iwats. - 2, 4, 5, 7, 10, 12: soil; 14: tree roots in a ditch

Plagiothecium curvifolium Limpr. - 3: bottom of Fagus

Plagiothecium laetum Schimp., (LC-att) - 8: soil

Plagiothecium nemorale (Mitt.) A. Jaeger - 1: Fagus bark; 2: soil

Plagiothecium platyphyllum Mönk., (DD) - 5: bottom of Alnus

Platygyrium repens (Brid.) Schimp. - 1: decaying wood, bark of Fagus and Quercus; 3: decaying wood; 4, 8: bark of Fagus and Quercus; 5, 7: Fraxinus bark; 9: bark of Carpinus, Quercus cerris and Q. petraea; 10: Salix bark; 12: Fagus bark; 14: Quercus bark

Poblia lutescens (Limpr.) H. Lindb., (LC-att) - 2: soil

Poblia melanodon (Brid.) A.J. Shaw - 1, 4, 5, 7, 8, 9, 12: soil; 11: soil on the bank of a stream

Polytrichum formosum Hedw. - 1, 2, 4, 5, 8, 10, 12: soil

Pseudoleskeella nervosa (Brid.) Nyholm - 2, 9: Quercus bark; 12: Fagus bark Pseudotaxiphyllum elegans (Brid.) Z. Iwats., (NT) - 8: soil

Pterigynandrum filiforme Hedw. - 1, 3: Fagus bark; 9: bark of Fagus and Quercus

Pylaisia polyantha (Hedw.) Schimp. - 1, 9: bark of Fagus and Quercus; 2, 8, 14: Quercus bark; 4, 6, 12: Fagus bark; 5, 7: Fraxinus bark; 10: Salix bark

Rhizomnium punctatum (Hedw.) T. J. Kop. - 3: decaying wood in a ditch; 8: soil and decaying wood; 11: soil on the bank of a stream

Tetraphis pellucida Hedw., (LC-att, indicator) - 7: decaying wood

Thuidium philibertii Limpr., (LC-att) - 2: soil

Thuidium recognitum (Hedw.) Lindb., (LC-att) - 1: bottom of Quercus

Tortula latifolia Bruch ex Hartm., (NT) - 9: Fagus bark

Tortula papillosa Wilson, (LC-att, indicator) - 4: Fagus bark; 9: bark of Fagus, Quercus cerris and Q. petraea; 10: Salix bark

Ulota crispa (Hedw.) Brid., (NT, indicator) - 1, 3: Fagus bark; 14: Carpinus bark

Ulota crispula Bruch - 1, 6: Fagus bark; 2, 4, 9: Quercus bark; 7: Fraxinus bark; 8: bark of Fagus and Carpinus

Ulota intermedia Schimp. - 1: Fagus bark 